\title{
Phage Types of Salmonella enterica ssp. enterica serovar Typhimurium Isolated from Production Animals and Humans i Denmark
}

\author{
By D. L. Baggesen and H. C. Wegener \\ Danish Veterinary Laboratory, Copenhagen, Denmark.
}

\begin{abstract}
Baggesen, D. L. and H. C. Wegener: Phage types of Salmonella enterica ssp. enterica serovar Typhimurium isolated from production animals and humans in Denmark. Acta. vet. scand. 1994, 35, 349-354. - S. Typhimurium is one of the 2 most common salmonella serotypes causing human salmonellosis in Denmark. In order to illustrate the significance of different production animals as a source of infection, 1461 isolates were characterized by phage typing. The isolates originated from human patients and from cattle, pigs and poultry. By phage typing the isolates could be separated in 35 different phage types. Five types $(10,12,66,110$ and 135$)$ predominated and comprised $78.8 \%$ of the isolates. In humans, $57.3 \%$ of the isolates were phage type 12 . This phage type was also predominant in pig herds and, to a lesser degree, in cattle. Phage types 110 , 120,135 and 193 constituted $86.5 \%$ of the poultry isolates while these phage types only made up $12.9 \%$ of the human isolates. The investigation showed that pigs are probably a major source of $S$. Typhimurium infection in humans in Denmark today.
\end{abstract}

Epidemiology; typing; infection source.

\section{Introduction}

Salmonella infection is the main cause of human gastroenteritis in Denmark. The annual number of reported cases increased throughout the 1980's reaching a maximum of 3495 in 1988. The 2 most common serotypes are Salmonella enterica ssp. enterica serovar Typhimurium (subsequently $S$. Typhimurium) and Salmonella enterica ssp. enterica serovar Enteritidis (subsequently $S$. Enteritidis) both of which ranked as the top 2 serotypes throughout the period (Fig. 1) (Gaarslev, personal communication 1944).

After 1988 there was a decrease in the total number of cases (Gaarslev 1989), but recently the prevalence has increased again (Fig. 1). During the autumn of 1992 in particular, there was a significant increase and the total for the year was 3133 cases, which represent an in- crease of $40 \%$ compared to 1991 (Gaarslev 1992). In 1992 the isolation numbers of $S$. Typhimurium and $S$. Enteritidis were 1158 and 1397, respectively.

Non-typhoid human salmonellosis is primarily caused by contaminated foodstuffs of animal origin. Poultry has been implicated as the main source in a number of countries (Khakhria et al. 1983, Humphrey et al. 1988, Reilly et al. 1988). Cattle are also generally recognised as an important source (Kirby \& Wray 1986, Humphrey et al. 1988) while the significance of pigs is more doubtful. From The Netherlands, Oosterom (1991) has reported that pigs as well as poultry represent a major source of human salmonellosis.

In Denmark, foodproducts derived from cattle and poultry have been incriminated as major sources of human salmonellosis (Baggesen 


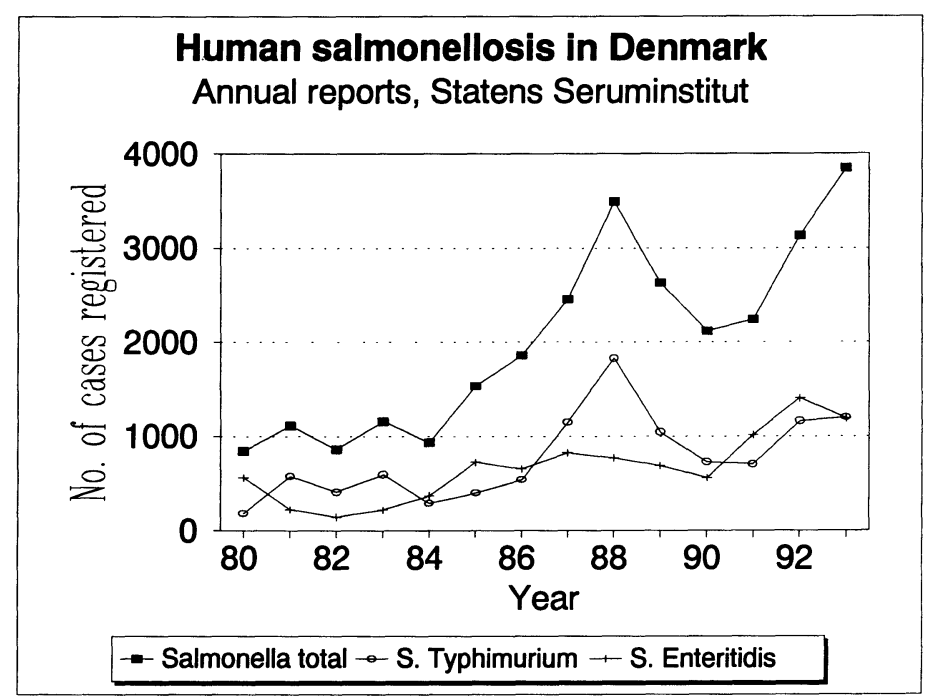

Figure 1. Isolation af Salmonella from human cases of salmonellosis in Denmark, 1980-1993.

1992). As a consequence of the high level of infection detected in poultry, a voluntary salmonella control programme for the broiler industry has been implemented by The Danish Poultry Council since 1989 in order to reduce the risk of transmission and infection with Salmonella enterica in humans (Bisgaard 1991). There has, however, been no continuous monitoring of clinical and subclinical salmonellainfections in other production animals. It is therefore difficult to evaluate the importance of the different sources of human salmonellosis. The number of registered cattle farms with clinical salmonellosis caused by $S$. Typhimurium has been fairly constant through the 1980 's, while the incidence of salmonellosis caused by both $S$. Typhimurium and other salmonella serotypes among pigs has increased since 1987. (Wegener et al. 1994).

The aim of this study was to make a survey of the distribution of phage types of $S$. Typhimurium from production animals including cattle, pigs and poultry. In addition the results were compared with those obtained from human isolates from the same period to examine a possible relation between human infection and animal sources.

\section{Materials and metods}

A collection of $1461 S$. Typhimurium isolates from the second part of 1992 (1/7 - 31/12 1992) was investigated. The origin of the strains is shown in Table 1. From production animals, up to 7 isolates per production unit (cattle or pig herd or poultry flock) were included. Single isolates from the human patients were included.

The animal material comprised $S$. Typhimurium isolates from samples of faeces or organs forwarded to the Danish Veterinary Laboratory for microbiological investigation. All animal isolates were serotyped according to the Kauffmann-White scheme (Popoff \& Le Minor 1992). The isolates were stored as sugarfree stabcultures (Bacto-agar 0140-01; Difco) or on Columbia agarplates (Oxoid CM331). 
Table 1. Origin of 1461 Danish $S$. Typhimurium isolates from the period 1/7 - 31/12 1992.

\begin{tabular}{llcc}
\hline Source & Type of infection & No. of units ${ }^{1}$ & No. of isolates $^{2}$ \\
\hline Cattle & Clinical & 54 & $82^{\mathrm{a}}$ \\
Pigs & Clinical & 89 & $170^{\mathrm{b}}$ \\
Pigs & Subclinical & 20 & $43^{\mathrm{c}}$ \\
Poultry & Subclinical & 172 & $335^{\mathrm{d}}$ \\
Human & Clinical & 831 & 831 \\
\hline
\end{tabular}

1: The unit of investigation were for cattle- and swine isolates the herd, for poultry isolates the flock, and for human isolates the patient.

Origin of isolates (No.):

a: Feces (66), mesenterium lgl. (5), intestine (2), liver (3), foetus (3), spleen (1), lung (1), placenta (1)

b: Feces (122), intestine (34), foetus (5), mesenterium lgl. (2), liver (2), spleen (2), lung (1), uterus (1), liquid manure (1)

c: Caecum contents (21), feces (18), intestine (2), navel (2)

d: Caecal tonsil, broilers (297), organs/broilers (17), organs/hens (13), egg shells (5), cloacal swabs (3)

Table 2. Distribution of Salmonella Typhimurium phage types (PT) among production animals and humans.

\begin{tabular}{|c|c|c|c|c|c|c|c|c|c|c|}
\hline \multirow[b]{2}{*}{ PT } & \multicolumn{2}{|c|}{ Cattle } & \multicolumn{2}{|c|}{$\begin{array}{c}\text { Pigs, } \\
\text { subclinical } \\
\text { infection }\end{array}$} & \multicolumn{2}{|c|}{$\begin{array}{c}\text { Pigs, } \\
\text { clinical } \\
\text { infection }\end{array}$} & \multicolumn{2}{|c|}{ Poultry } & \multicolumn{2}{|c|}{ Human } \\
\hline & No.* & $(\%)$ & No. & $(\%)$ & No. & $(\%)$ & No. & $\overline{(\%)}$ & No. & $(\%)$ \\
\hline 8 & & & & & & & 1 & $(0.5)$ & 9 & $(1.0)$ \\
\hline 10 & 6 & (10.9) & 3 & $(13.0)$ & 5 & $(5.4)$ & & & 94 & (11.3) \\
\hline 12 & 20 & $(36.4)$ & 8 & $(34.8)$ & 65 & (69.9) & 1 & $(0.5)$ & 476 & (57.3) \\
\hline $15 \mathrm{a}$ & 1 & (1.8) & & & & & & & 9 & (1.0) \\
\hline 17 & 2 & (3.6) & 4 & $(17.4)$ & 3 & (3.2) & & & 3 & $(0.4)$ \\
\hline 66 & 6 & (10.9) & 3 & $(13.0)$ & 6 & (6.5) & 3 & (1.4) & 39 & (4.7) \\
\hline 110 & 6 & (10.9) & 2 & (8.7) & 3 & (3.2) & 76 & (36.7) & 50 & $(6.0)$ \\
\hline 120 & 4 & (7.3) & & & & & 20 & (9.7) & 6 & $(0.7)$ \\
\hline 135 & 3 & (5.5) & & & 3 & (3.2) & 58 & $(28.0)$ & 17 & $(2.0)$ \\
\hline 177 & & & 1 & (4.3) & 1 & (1.1) & 2 & $(1.0)$ & 1 & $(0.1)$ \\
\hline 193 & 2 & (3.6) & & & 6 & (6.5) & 25 & (12.1) & 35 & (4.2) \\
\hline 195 & 1 & (1.8) & & & 1 & (1.1) & & & 2 & $(0.2)$ \\
\hline RDNC** & 4 & (7.3) & 2 & (8.7) & & & 4 & (1.9) & 42 & $(5.0)$ \\
\hline NT*** & & & & & & & 5 & (2.4) & 7 & $(0.8)$ \\
\hline
\end{tabular}

* $\quad$ No. of epidemiological units with $S$. Typhimurium of the specific phage type.

** RDNC - Rutine Dilution No Conformity.

*** NT - Non Typable. 
The human isolates were isolated and serotyped at Statens Seruminstitut, Copenhagen, Denmark, from where they were received as sugar-free stabcultures (Ekstract agar, Statens Seruminstitut, Copenhagen, Denmark).

All isolates were phage typed according to Callow (1959) using the extended phage typing scheme for $S$. Typhimurium (Anderson et al. 1977). Typing phages and type strains were obtained from Dr. B. Rowe, Laboratory of Enteric Pathogens, Central Public Health Laboratories, Colindale, UK.

\section{Results}

A total of 1461 strains of $S$. Typhimurium isolated in the second part of 1992 were phage typed. Eight hundred and thirty one isolates originated from human cases of salmonellosis, while the remaining were isolated from various production animals (Table 1).

Phage typing subdivided the isolates into 35 different phage types including a group of 52 isolates which reacted with the typing phages without conforming any previously known phage type (RDNC) and a group of 12 which were non typable (NT). Thirteen isolates were phage infected. All isolates were phage typed, but for the animal isolates only 1 isolate of each phage type within a production unit was included in the statement (Table 2). Simultaneous infections with 2 different phage types were observed in 35 herds/flocks (cattle herds: 1; pig herds: 7; poultry flocks: 28) whereas infections with 3 and 4 phage types were observed in 2 and 1 poultry flock, respectively.

Five phage types $(10,12,66,110$ and 135$)$ predominated and comprised $78,8 \%$ of the isolates. Fourteen phage types was seen in more than 1 group (Table 2) whereas the remaining 21 phage types (PT 1, 2, 12a, 13, 32, 36, 41, 49, $67,69,77,85,86,89,93,99,104,111,161,186$ and 194) only were seen in 1 group most commenly among the human isolates.

Different phage types predominated within the different populations. Of the human isolates, $57.3 \%$ were phage type 12 , while $11.3 \%$ and $4.7 \%$ were phage type 10 and 66 , respectively. Phage type 12 , also predominated within isolates from pigs. It was isolated significantly more frequent from cases of clinical salmonellosis than from subclinical infections $(p=0.002)$. Phage types 12,10 and 66 were all frequently isolated from pigs and cattle. Phage types 110,120,135 and 193 were mainly associated with poultry production, constituting $86.5 \%$ of all isolates. These phage types comprised $12.9 \%$ of the isolates from the humans (Table 2).

\section{Discussion}

The results of the present investigation demonstrated, that the most frequent phage type of $S$. Typhimurium isolates from humans in Denmark in the second half of 1992 was phage type 12 , followed by phage type 10 . When compared to phage type distribution in production animals, it was most likely that these infections were caused by food products of pig or cattle origin. The increase in clinical salmonellosis and subclinical salmonella infections among Danish pigs may indicate, that pig meat today is a major source of human $S$. Typhimurium infections in Denmark.

Poultry has previously been incriminated as a major source of human $S$. Typhimurium infections in Denmark (Baggesen 1992) as well as in other countries (Khakhria et al. 1983, Kirby \& Wray 1986, Humphrey et al. 1988, Reilly et al. 1988). In the present investigation, phage typing indicated that only a minor part of the human cases originated from poultry or poultry products because the isolation of poultry associated phage types from human was rela- 
tively low compared with pig associated types. Until recently there was no continuous monitoring of subclinical salmonella infections in production animals other than poultry in Denmark. A minor investigation of $S$. Typhimurium strains isolated from humans, poultry and cattle in 1987 indicated that human $S$. Typhimurium infections were caused in particular by phage types 66 and 110 and that these phage types might originate from both cattle and poultry (Baggesen 1992).

The present investigation indicated a change in the phage type pattern of $S$. Typhimurium from 1987 to 1992. This shift has been confirmed in a retrospective study of human $S$. Typhimurium isolated from 1988 to 1993 . The significance of phage type 12 as a cause of human salmonellosis increased dramatically between 1990 and 1991, while the significance of phage types 66 and 110 was reduced throughout the whole period (Wegener et al. 1994).

It is not possible to determine the exact prevalence of $S$. Typhimurium in the different animal populations. Salmonella infection in broiler flocks have decreased from approximately $80 \%$ to $12-15 \%$ since the implementation of the control programme, while less than $1 \%$ of the table egg producing flocks were infected (Anon. 1993). Important serotypes included Berta, Enteritidis and Typhimurium.

A currently ongoing screening programme, involving Danish pig herds has shown, that approximately $14 \%$ of the pig herds, are subclinically infected with salmonella of which one third is S. Typhimurium (Holst 1993).

At the moment only little is known about the level and significance of subclinical $S$. Typhimurium infection in cattle. It is therefore difficult to evaluate to which extend beef might be a risk to the human population.

This investigation has shown, that phage typing of $S$. Typhimurium may be useful in estab- lishing relations between human illness and potential animal sources at the herd/flock level. Typing should however be performed continuosly, as opposed to screening investigations of limited duration, because the occurence of specific types in animals and man may be displaced in time (Olsen et al. 1992). Phage typing has shown to be a useful surveillance method as it is definitive, stable, easy to perform and cheap and the method is used in several other countries (Old \& Barker 1989, Threlfall \& Frost 1990). In addition to phage typing other epidemiological markers as plasmid profiling, ribotyping or pulsed field gel electrophoresis may be useful to give more detailed informations on relations within a selected material. These methods are, however, too expensive and time consuming for continuous examination of large numbers of strains (Threlfall \& Frost 1990).

\section{Acknowledgements}

We wish to thank Dr. K. Gaarslev, Statens Seruminstitut, Dr. H.C.Hansen and Dr. B.B.Nielsen, Danish Veterinary Labotatory for the supply of cultures and epidemiological informations used in this study, and Eva Petersen and Sussi-Kristoffersen for technical assistance. The study was supported by Grant no. RÅ92-SVS-1.

\section{References}

Anderson ES, Ward LR, DeSaxe MJ, DeSa JDH: Bacteriophage-typing designations of Salmonella typhimurium. J. Hyg. Camb 1977, 78, $297-$ 300.

Anonymous: Annual reports from the Danish Poultry Council. 1992, 94 pp.

Baggesen DL: Epidemiological markers for Salmonella typhimurium infections (Antibiogram, Plasmid profilling and Phage typing) (Ph.D. thesis). Copenhagen, The Royal Veterinary and Agricultural University, $1992.138 \mathrm{pp}$.

Bisgaard $M$ : A voluntary salmonella control programme for the broiler industry implemented by the Danish Poultry Council. Int. J. Food Microbiol 1991, 15, 219-24. 
Callow BR: A new phage-typing scheme for Salmonella Typhi-murium. J. Hyg. Camb. 1959, 57, 34659.

Gaarslev K: Salmonella udviklingen i 1989 (Development of Salmonella in 1989). EPI-NYT 1989, no. 42.

Gaarslev K: Salmonella-infektioner er igen aktuelle (Salmonella infections are still of current interest). EPI-NYT 1992, no. 50.

Holst S: Forekomst af Salmonella i caecun hos danske slagtesvin (Salmonella infection in Danish slaughterpigs). Dansk VetTidsskr. 1993, 76, 645-652.

Humphrey TJ, Mead GC, Rowe B: Poultry meat as a source of human salmonellosis in England and Wales. Epidmiol. Infect. 1988, 100, 175-84.

Khakhria R, Bezanson $G$, Duck D, Lior H: The epidemic spread of Salmonella typhimurium phage type 10 in Canada (1970-1979). Can. J. Microbiol. 1983, 29, 1583-88.

Kirby $D$, Wray $C$ : Veterinary aspects and prospects for control. Public Health Laboratory Service Microbiology Digest 1986, 3, 12-13.

Old DC, Barker RM: Persistent and transient clones of Salmonella typhimurium of phage type 141 recognized by biotyping. Epidemiol. Infect. 1989, 102, 113-118.

Olsen JE, Sørensen M, Brown DJ, Gaarslev K, Bisgaard $M$ : Plasmid profiles as an epidemiological marker in Salmonella enterica serovar berta infections. Acta pathol. microbiol. immunol. scand. 1992, 100, 221-228.

Oosterom J: Epidemiological studies and proposed preventive measures in the fight against human salmonellosis. Int. J. Food Microbiol. 1991, 12, 41-52.

Popoff MY, Le Minor L: Antigenic formulas of the Salmonella serovars. WHO Collaborating Cen- ter for Reference and Research on Salmonella. Institut Pasteur, Paris, France. 1992.

Reilly WJ, Forbes GI, Sharp JCM, Oboegbulem SI, Collier PW, Paterson GM: Poultry-borne salmonellosis in Scotland. Epidemiol Infect. 1988, 101, 115-22.

Threlfall E J, Frost $J$ A: The identification, typing and fingerprinting of Salmonella: laboratory aspects and epidemiological applications. J. Appl. Bacteriol. 1990, 68, 5-16.

Wegener HC, Baggesen DL, Gaarslev K: Salmonella Typhimurium phage types from human salmonellosis in Denmark 1988 to 1993. Acta pathol. microbiol. immunol. scand. 1994, 102, 521-525.

\section{Sammendrag}

Fagtyper af Salmonella enterica ssp. enterica serovar Typhimurium isoleret fra produktionsdyr og mennesker i Danmark.

S. Typhimurium er den ene af de to hyppigste årsager til human salmonellose i Danmark. Med henblik på at belyse betydningen af forskellige produktionsdyrs betydning som smittekilde er 1461 isolater blevet karakteriseret ved fagtypning. Isolater fra kvæg, svin og fjerkræ er sammenlignet med isolater fra mennesker. Fagtypning kunne inddele det samlede materiale i 35 typer, hvoraf 5 typer $(10,12$, 66,110 og 135 ) alene udgjorde $78,8 \%$. Blandt humane isolater tilhørte $57,3 \%$ fagtype 12 . Denne fagtype var også dominerende blandt isolater fra svin og i mindre udstrækning blandt isolater fra kvæg. Fagtyperne 110, 120, 135 og 193 udgjorde 86,5\% af fjerkræisolaterne, men disse fagtyper udgjorde kun $12,9 \%$ af de humane isolater. Undersøgelsen antyder, at svin i dag udgør en væsentlig kilde til human salmonellose forårsaget af $S$. Typhimurium i Danmark.

(Received March 16, 1994; accepted June 3, 1994)

Reprints may be requested from: D. L. Baggesen, DanishVeterinary Laboratory, Bülowsvej 27, DK-1790 Copenhagen V, Denmark. 